\title{
Growth Rate Differences among Big Sage- brush [Artemisia tridentata] Accessions and Subspecies
}

\author{
E. DURANT MCARTHUR AND BRUCE L. WELCH
}

\author{
Abstract
}

Even-aged plants of 21 big sagebrush (Artemisia tridentata) accessions were grown in a uniform garden to test growth parameter variation. Growth parameters measures (height, crown diameter, yield, and annual nonfloral leader growth) were scored after the 1975, 1976, and 1977 growing seasons. Nested analyses of variance and mean comparison tests showed significant $(p<0.05)$ accession and subspecies differences in each measure, each year. On a subspecies level, basin big sagebrush (A.t. ssp. tridentata) exceeded the other two subspecies (mountain big sagebrush $=A$.t. vaseyana, Wyoming big sagebrush $=A$.t. wyomingensis) for each character. In general, the values for the last two subspecies were not significantly different, but mountain big sagebrush tended to have larger values. Using 1975 data for yield and 1976 data for the other growth parameters, basin big sagebrush accessions averaged $147.9 \pm 14.7$ (se) $\mathrm{cm}$ in height, $193.0 \pm 12.1 \mathrm{~cm}$ in maximum crown spread, $2217 \pm 444 \mathrm{~g}$ current yield, and $12.7 \pm 1.1 \mathrm{~cm}$ in annual leader growth. Corresponding values for mountain big sagebrush were $95.8 \pm 2.2 \mathrm{~cm}, 157.3 \pm 3.4 \mathrm{~cm}, 890 \pm 77 \mathrm{~g}$, and $8.8 \pm 0.6 \mathrm{~cm}$. For Wyoming big sagebrush the values were $77.1 \pm 4.1 \mathrm{~cm}, 129.6 \pm$ $6.4 \mathrm{~cm}, 545 \pm 84 \mathrm{~g}$, and $8.5 \pm 1.1 \mathrm{~cm}$. Comparison of three accessions' performances at two uniform gardens and their native sites indicated that growth parameters, while subject to environmental influences, are under genetic control. The fastest growing and largest growing plants of this study were diploid, $2 n=18$, whereas, the slowest growing ones were tetraploid, $2 n=36$. Growth rate characteristics of big sagebrush should be considered for management purposes and in plant improvement programs.

Big sagebrush (Artemisia tridentata Nutt.) is among western North America's most widely distributed shrub species and is the most abundant single species (Beetle 1960, McArthur and Plummer 1978, McArthur et al. 1979). With its relatives, it forms the subgenus Tridentatae-recently elevated from sectional status (McArthur et al. 1981). The Tridentatae, endemic to western North America, form a natural phylogenetic group consisting of several well-defined species as well as a few taxa with fuzzy limits (Ward 1953; Beetle 1960, 1971; McArthur 1979). Big sagebrush itself has been divided into three subspecies and several forms (Beetle and Young 1965, Winward and Tisdale 1977, McArthur et al. 1979).

\footnotetext{
The authors are principal research geneticist and principal plant physiologist, Intermountain Forest and Range Experiment Station, Ogden, Utah 84401 . Both are stationed at the Intermountain Station's Shrub Sciences Laboratory, Provo, Utah 84601 and are adjunct faculty members of the Brigham Young University Botany Department.

Federal funds for wild life restoration were provided through Pittman-Robertson Project W-82-R (Cooperators: Intermountain Forest and Range Experiment Station of USDA Forest Service and Utah Division of Wild life Resources). The Snow Field Station is cooperatively maintained by the above two agencies, Utah State University and Snow College. The Gordon Creek Wild life Management Area is maintained by the Utah Division of Wildlife Resources. A. Perry Plummer (retired), Intermountain Forest and Range Experiment Station, made this study possible by his perceptive collection of sagebrush accessions. We thank A.C. Blauer, B.C. Giunta. G.L. Jorgensen, C.M. McKell, and personnel of the Utah Division of Wildlife Resources for helpful discussion, technical assistance, and plot maintenance.

Manuscript received June 29, 1980.
}

Subspecies and lower taxonomic levels including individual accessions or populations are distinct and may require differential management (Winward and Tisdale 1977, McArthur and Plummer 1978, Welch and McArthur 1979a, Nelson and Krebill 1981).

Within the context of populational variability, we see the opportunity for selective use of existing natural material in land rehabilitation efforts (Plummer 1977) and beyond that to the genetic improvement of plant stocks for particular purposes (Welch and McArthur 1979a). This report is the fourth in a series demonstrating accessional and subspecies variability of big sagebrush in uniform garden situations. Earlier, we showed protein (Welch and McArthur 1979b), monoterpenoid (Welch and McArthur 1981), and in vitro digestibility (Welch and Pederson 1981) differences among accessions representing the three subspecies of big sagebrush. Here, we report on growth parameter differences. It has been known for some time that enormous size differences existed in big sagebrush (Pool 1908, Kearney et al. 1914). Beetle $(1960,1962)$ first ascribed some of these differences to taxonomic or genetic causes. Winward (1970) showed varying amounts of stem diameter correlation with plant age for the big sagebrush subspecies. Other observers have noted, however, that plant size correlates poorly with plant age in big sagebrush (Cottam and Stewart 1940, Ferguson 1964, Roughton 1972, Daubenmire 1975).

\section{Materials and Methods}

\section{Plant Materials}

Accessions representing about 80 natural populations of big sagebrush have been established at the Snow Field Station, Ephraim, Utah. Plants have been collected as young wildings and transplanted as bare-root stock to rows in the Snow Field Station either in the spring (March-June) or in the fall (OctoberNovember). Many of these accessions have also been established at the Gordon Creek Wildlife Management area near Helper, Utah, and at other small outplanting sites. The 21 accessions of this study (Table 1) represent the three big sagebrush subspecies; basin big sagebrush (A.t. ssp. tridentata), mountain big sagebrush (A.t. ssp. vaseyana (Rydb.) Beetle), and Wyoming big sagebrush (A.t. ssp. wyomingensis Beetle and Young). The 21 accessions were chosen because they were established about the same time (1970), they represent a fairly broad geographic and elevational range (Table 1), they encompass much of big sagebrush's morphological variability, and they are growing on a homogenous 1.5 ha section of the Snow Field Station. The plants were irrigated only once to aid establishment. Weed control was exercised by manual and mechanical means.

The 21 accessions have chromosome numbers mostly at the characteristic diploid $(2 n=18)$ and tetraploid $(2 n=36)$ levels of big sagebrush (Ward 1953, McArthur et al. 1981). Two accessions have mixed chromosome numbers, a phenomenon not unknown in the Tridentatae (McArthur et al. 1981).

Subspecies determinations were made following the key of 
McArthur et al. (1979). Chemical tests (Hanks et al. 1973, Stevens and McArthur 1974) were also used as an aid to taxonomic identification. Representative specimens of each accession are deposited at the Shrub Sciences Laboratory Herbarium (SSLP).

\section{Study Sites}

The principal study site was the Snow Field Station. This facility, immediately northeast of Ephraim, Utah, is in Sanpete Valley. It is a former basin big sagebrush site later converted to agricultural uses. About 20 ha are presently assigned to shrub genetics, seed production, adaptation, and related research activities. The soil there is a deep alluvial limestone-derived clay. It is about $2 \mathrm{~km}$ west of the base of the monoclinal western front of the Wasatch Plateau. The Snow Field Station has an elevation of about $1700 \mathrm{~m}$. Annual precipitation for the $1959-1979$ period was $26.8 \mathrm{~cm}$ (data on file at Snow Field Station). Price and Evans (1937) reported $29.7 \mathrm{~cm}$ over a longer time period at a nearby site. They also stated that $45 \%$ of the precipitation comes in the winter (November 1 to April 30), mostly as snow. Data filed at the Snow Field Station (1959-1979) showed that about $53 \%$ of the precipitation came during the winter period.

A secondary study site was the Gordon Creek Wildlife Management Area about $15 \mathrm{~km}$ west of Helper, Utah. This site is at about $2130 \mathrm{~m}$ in elevation and receives about $28.6 \mathrm{~cm}$ precipitation annually (data on file at Great Basin Experimental Area, Ephraim, Utah). It is located in a valley formed by dissection of the eastern edge of the Wasatch Plateau. The site consists of about 2 ha of the much larger Wildlife Management Area. As at the Snow Field Station, the site is on agricultural land that had included big sagebrush in its original vegetation. The soil here is limestone derived as is that at the Snow Field Station, but has a sandier texture. A mule deer (Odocoileus hemionus Raf.) herd of more than 200 animals winters at and near the site.

Three natural big sagebrush populations were sampled in a preliminary attempt to access site impacts on growth parameters. These were the Dove Creek and Loa basin big sagebrush and the Colton mountain big sagebrush sites (Table 1). The Dove Creek site is about $2 \mathrm{~km}$ west of Dove Creek, Colo., in ar royo breaks in an agricultural area and along adjacent roads and fence rows. Black sagebrush ( $A$. nova Nelson) occurs in the rocky outcrops of the arroyo breaks. The Loa site is about $8 \mathrm{~km}$ west of Loa, Utah, in a basin big sagebrush community of undulating topography adjacent to the Fremont River Valley. The Colton site is on the
Wasatch Plateau in a large mountain big sagebrush community in Utah County, Utah.

\section{Data Collection and Analyses}

Accessions at the Snow Field Station were sampled for height, crown, and annual plant yield in 1975 and for height, crown, and annual leader growth in 1977 and 1978. Five plants from each accession were sampled. Plants were required to be healthy, but otherwise were taken at random. Height $(\mathrm{cm})$ was measured to the highest vegetative point on the plant. Maximum crown $(\mathrm{cm})$ was measured across each plant's largest crown diameter. Current annual forage yield ( $\mathrm{g}$ of leaves and twigs) was estimated using the ocular method of Pechanec and Pickford (1937). Annual leader growth $(\mathrm{cm})$ was determined by measuring the length of 10 twigs distally from the current year's bud scar. Five of the twigs or leaders were randomly picked from branches with an axis more horizontal than vertical and five more from branches with more vertical axes. The 1975 data were taken in summer (August). The 1977 and 1978 data collections were taken in late winter (March). Even though big sagebrush is everg reen and photosynthesizes year round (Pearson 1975), its vegetative growth occurs in the late spring and early summer, diminishing sharply in summer (midJuly) (DePuit and Caldwell 1973; Caldwell 1979). Our summer (1975) and winter $(1977,1978)$ data collections, therefore, were taken after the effective growing seasons of 1975, 1976, and 1977. Data collection at the Gordon Creek Wildlife Management Area and the three natural sites was performed in the same manner as at the Snow Field Station.

At Gordon Creek, sample plants were randomly picked from accessional rows. Plants at the native sites, however, were selected by arbitrarily picking a transect direction and then sampling every fifth, healthy, mature plant. Plants were deemed mature if they (1) had produced flower stalks and (2) were $>45 \mathrm{~cm}$ in height. In natural big sagebrush populations, seedlings are produced regularly, but not every year. New individuals are established, however, only when the plant community opens up-sporadically through individual deaths or as a modal class after a catastrophic disturbance, such as fire or chaining (Harniss and Murray 1973, Daubenmire 1975).

Data analyses were performed through nested analysis of variance technique (Snedecor and Cochran 1967). When warranted by the analysis of variance results, accession and subspecies means were tested for significance. Tukey's post hoc mean comparison

Table 1. Big sagebrush accessions studied.

\begin{tabular}{|c|c|c|c|c|}
\hline Subspecies & Accession collection site & $\begin{array}{l}\text { Culture } \\
\text { number }\end{array}$ & $\begin{array}{l}\text { Elevation } \\
\text { (m) }\end{array}$ & $\begin{array}{c}\text { 2n Chromosome } \\
\text { number }\end{array}$ \\
\hline Tridentata & $\begin{array}{l}\text { Loa, Wayne County, Utah } \\
\text { Dove Creek, Dolores County, Colorado } \\
\text { Wingate Mesa, San Juan County, Utah } \\
\text { Clear Creek Canyon, Sevier County, Utah } \\
\text { Dog Valley, Juab County, Utah } \\
\text { Brush Creek, Uintah County, Utah } \\
\text { Evanston, Uinta County, Wyoming }\end{array}$ & $\begin{array}{l}U-44 \\
U-74 \\
U-75 \\
U-76 \\
U-79 \\
U-82 \\
U-105\end{array}$ & $\begin{array}{l}2140 \\
2070 \\
2060 \\
1720 \\
1700 \\
1830 \\
2050\end{array}$ & $\begin{array}{l}18 \\
18 \\
36 \\
18 \\
18 \\
36 \\
18\end{array}$ \\
\hline Vaseyana & $\begin{array}{l}\text { Benmore, Tooele County, Utah } \\
\text { Alton, Kane County, Utah } \\
\text { Indian Peaks, Beaver County, Utah } \\
\text { Colton, Utah County, Utah } \\
\text { Sardine Canyon, Cache County, Utah } \\
\text { Salina Canyon, Sevier County, Utah } \\
\text { Pinto, Washington County, Utah } \\
\text { Clear Creek Canyon, Sevier County, Utah } \\
\text { Durkee Springs, Piute County, Utah } \\
\text { Petty Bishop's Log, Sanpete County, Utah }\end{array}$ & $\begin{array}{l}U-9 \\
U-11 \\
U-13 \\
U-14 \\
U-15 \\
U-19 \\
U-23 \\
U-24 \\
U-31 \\
U-72\end{array}$ & $\begin{array}{l}1900 \\
2100 \\
2140 \\
2260 \\
1800 \\
2350 \\
1850 \\
2130 \\
2270 \\
2380\end{array}$ & $\begin{array}{l}18 \\
18 \\
18 \\
36 \\
18 \\
18,36 \\
36 \\
18 \\
18 \\
18\end{array}$ \\
\hline Wyomingensis & $\begin{array}{l}\text { Trough Springs, Humboldt County, Nevada } \\
\text { Milford, Beaver County, Utah } \\
\text { Evanston, Uinta County, Wyoming } \\
\text { Kaibab, Coconino County, Arizona }\end{array}$ & $\begin{array}{l}U-1 \\
U-17 \\
U-37 \\
U-80\end{array}$ & $\begin{array}{l}1400 \\
1540 \\
2130 \\
2340\end{array}$ & $\begin{array}{l}36,54 \\
36 \\
36 \\
36\end{array}$ \\
\hline
\end{tabular}

IFrom McArthur et al. 1981. 
Table 2. Nested analyses of variance for growth parameters of big sagebrush at the Snow Field Station (1976 growing season).

\begin{tabular}{|c|c|c|c|c|c|c|c|c|c|c|c|c|}
\hline \multirow[b]{2}{*}{ Source } & \multicolumn{4}{|c|}{ Annual leader growth } & \multicolumn{4}{|c|}{ Crown } & \multicolumn{4}{|c|}{ Height } \\
\hline & D.F. & S.S. & M.S. & $\mathrm{F}^{\prime}$ & D.F. & S.S. & M.S. & $F^{1}$ & D.F. & S.S. & M.S. & $\mathrm{Fl}^{\prime}$ \\
\hline Subspecies & 2 & 5,156 & 2,578 & $5.5^{*}$ & 2 & 58,321 & 29,160 & $10.2 * *$ & 2 & 82,070 & 41,035 & $15.2^{* *}$ \\
\hline Accessions & 18 & 8,513 & 473 & $15.8^{* *}$ & 18 & 51,635 & 2,869 & $2.9 * *$ & 18 & 48,453 & 2,692 & $12.2^{* *}$ \\
\hline Plants & 84 & 2,498 & 30 & $1.8^{* *}$ & 84 & 82,966 & 988 & - & 84 & 18,523 & 221 & - \\
\hline Branches & 945 & 16,894 & 18 & - & & - & - & - & - & - & - & - \\
\hline Total & 1,049 & 33,061 & & & 104 & 192,922 & & & 104 & 149,046 & & \\
\hline
\end{tabular}

${ }^{1}$ Level of significance for $F$ values is indicated by ${ }^{*} p<0.05$ and ${ }^{* *} p<0.01$.

test was used for accessional comparisons. In making subspecies comparisons with different sample sizes (Table 1), however, a Scheffe's test was deemed more appropriate (Steele and Torrie 1960, Hays 1963). Growth rate indexes were constructed so that $200 \mathrm{~cm}$ in height $=33.3$ units, $250 \mathrm{~cm}$ crown $=33.3$ units and, alternatively, $3000 \mathrm{~g}$ yield (1975) or $15 \mathrm{~cm}$ annual leader growth $(1976,1977)=33.3$ units. Gaged by this index, plants with large growth parameters would approach or exceed 100 units.

\section{Results}

\section{Accessional Differences at the Snow Field Station}

For all 3 years of the study, accessions showed highly significant $(p<0.01)$ differences among the growth parameters: height, crown, annual leader growth, and yield. The data for 1976 are illustrated in Table 2. Mean heights (Table 3) ranged from 69.2 to $221.2 \mathrm{~cm}$. For crowns, the range was from 111.4 to $249.2 \mathrm{~cm}$. Annual leadergrowth means varied from 5.6 to $15.4 \mathrm{~cm}$. Current annual-yield means ranged from 350 to $3680 \mathrm{~g}$. Many of these mean differences were highly significant $(p<0.01)$ (Table 3 ).

The growth rate indices (Table 4 ) reflect consistent growth parameter differences among accessions from year to year. In general, the 3-year patterns are about the same. It must be remembered the index was calculated differently from 1975 than for the other 2 years. Some of the movement in the table is, perhaps, attributable to different individual bushes being sampled the various years. Another cause may be a differential accessional response to the 2-year (1976-1977) drought (Richardson et al. 1977, McArthur and Freeman 1981). We believe the last cause, through self pruning and lower annual production, to be a primary cause for the generation of lower indices for all but one accession for 1977 as compared to 1976. Four accessions are missing for the 1977 analysis (Table 4) due to excessive mortality and poor health.

\section{Intersite Comparison of Accessions}

Our preliminary comparisons of the growth parameters of three accessions at two uniform gardens and the natural sites of each accession showed accessional and site consistency (Table 5). In each case, the plants at the Snow Field Station performed best, often significantly better $(p<0.01)$. Plant performance at the native sites and the Gordon Creek Wildlife Management Arca followed generally in that order. Only two out of eight mean comparisons were significantly different for the latter sites (Gordon Creek versus native). At each site, the accessional order of growth parameter performance was Dove Creek $>$ Loa $>$ Colton.

There are, however, several complicating factors. The different age structure of the native site plants must be borne in mind for comparisons. Furthermore, the Gordon Creek site has an additional complication in that the shrubs there are browsed by wintering mule deer and browsed differentially (Hanks et al. 1973, Scholl et al. 1977, Welch et al. 1981). Because of man's activities and the snow depth, browsing rarely occurs at the other sites. The data, nevertheless, are interpretable on the basis of genetic differences. The plants perform differently on different sites, but maintain coherent patterns.

\section{Subspecies Comparison}

Subspecies effects were responsible for a significant portion of the variation in all growth parameter values (Table 2). Subspecies effects are especially strong on height, crown, and yield $(p<0.01)$ as

Table 3. Growth characteristics of big sagebrush accessions at the Snow Field Station.

\begin{tabular}{|c|c|c|c|c|c|c|}
\hline Accession & $\operatorname{ssp} p^{1}$ & $\begin{array}{l}\text { Height } \\
(\mathrm{cm})\end{array}$ & $\begin{array}{l}\text { Crown }{ }^{2} \\
(\mathrm{~cm})\end{array}$ & Height/crown & $\begin{array}{c}\text { Annual leader } \\
\text { growth } \\
\text { (cm) }\end{array}$ & $\begin{array}{c}\text { Annual yield } 2 \\
\text { (g) }\end{array}$ \\
\hline Dove Creek & t & $221.2 \mathrm{a}^{3}$ & $249.2 \mathrm{a}^{3}$ & 0.89 & $15.1 \mathrm{a}^{3}$ & $3,680 \mathrm{a}^{3}$ \\
\hline Clear Creek & $\mathrm{t}$ & $162.2 \mathrm{~b}$ & $233.0 \mathrm{ab}$ & .70 & $14.5 \mathrm{ab}$ & $3,020 \mathrm{ab}$ \\
\hline Loa & $t$ & $156.8 \mathrm{~b}$ & $200.2 \mathrm{abc}$ & .78 & $15.4 \mathrm{a}$ & $3,510 \mathrm{a}$ \\
\hline Evanston & $t$ & $140.0 \mathrm{bc}$ & $170.6 \mathrm{abcd}$ & .82 & $14.0 \mathrm{abc}$ & $1,530 \mathrm{c}$ \\
\hline Dog Valley & $t$ & $138.4 \mathrm{bcd}$ & $193.2 \mathrm{abc}$ & .72 & $12.1 \mathrm{abcd}$ & $1,760 \mathrm{bc}$ \\
\hline Wingate Mesa & $\mathrm{t}$ & $116.4 \mathrm{cde}$ & $175.6 \mathrm{abcd}$ & .66 & 10.2 abcde & $1,340 \mathrm{c}$ \\
\hline Benmore & $\mathrm{v}$ & $106.6 \mathrm{cdef}$ & $167.4 \mathrm{abcd}$ & .64 & $7.6 \mathrm{de}$ & $750 \mathrm{c}$ \\
\hline Pinto & $\mathrm{v}$ & $104.0 \mathrm{cdef}$ & $152.8 \mathrm{bcd}$ & .68 & 9.3 abcde & $1,080 \mathrm{c}$ \\
\hline Alton & $\mathrm{v}$ & $101.6 \mathrm{cdef}$ & $158.8 \mathrm{bcd}$ & .64 & $7.7 \mathrm{cde}$ & $680 \mathrm{c}$ \\
\hline Brush Creek & $\mathrm{t}$ & 100.2 def & $138.6 \mathrm{~cd}$ & .73 & 7.7 cde & $680 \mathrm{c}$ \\
\hline Clear Creek & $\mathrm{v}$ & $98.2 \mathrm{ef}$ & $173.6 \mathrm{abcd}$ & .57 & 11.6 abcde & $1,140 \mathrm{c}$ \\
\hline Sardine Pass & $\mathrm{v}$ & $95.6 \mathrm{ef}$ & $148.0 \mathrm{~cd}$ & .65 & $7.4 \mathrm{dc}$ & $800 \mathrm{c}$ \\
\hline Petty Bishop's Log & v & $94.2 \mathrm{ef}$ & $153.0 \mathrm{bcd}$ & .62 & 8.2 bcde & $1,310 \mathrm{c}$ \\
\hline Colton & v & $92.6 \mathrm{ef}$ & $150.6 \mathrm{~cd}$ & .62 & $5.6 \mathrm{e}$ & $610 \mathrm{c}$ \\
\hline Durkee Springs & v & 89.6 ef & $171.6 \mathrm{abcd}$ & .52 & 10.9 abcde & $625 \mathrm{c}$ \\
\hline Milford & $\mathbf{w}$ & $88.6 \mathrm{ef}$ & $140.0 \mathrm{~cd}$ & .63 & 8.7 bcde & $550 \mathrm{c}$ \\
\hline Indian Peak & $\mathbf{v}$ & 88.4 ef & $141.2 \mathrm{~cd}$ & .63 & 9.3 abcde & $850 \mathrm{c}$ \\
\hline Salina Canyon & $\mathbf{v}$ & 86.8 ef & $156.0 \mathrm{bcd}$ & .56 & 9.9 abcde & $1,060 \mathrm{c}$ \\
\hline Kaibab & $w$ & $75.8 \mathrm{f}$ & $140.4 \mathrm{~cd}$ & .54 & $6.9 \mathrm{de}$ & $520 \mathrm{c}$ \\
\hline Evanston & $w$ & $74.6 \mathrm{f}$ & $126.2 \mathrm{~cd}$ & .59 & 11.4 abcde & $760 \mathrm{c}$ \\
\hline Trough Springs & $w$ & 69.2 f & $111.4 \mathrm{~d}$ & .62 & $6.9 \mathrm{de}$ & $350 \mathrm{c}$ \\
\hline
\end{tabular}

'Subspecies: $\mathrm{t}=$ tridentata, $\mathrm{v}=$ vaseyana, $\mathrm{w}=$ wyomingensis

'Height, crown, and annual leader growth for 1976 growing season; annual yield for 1975 growing season.

'Means in each column followed by the same letter are not significantly different $(p<0.01)$ by Tukey's test. 
Table 4. Growth rate indices ${ }^{1}$ of big sagebrush accessions at the Snow Field Station.

\begin{tabular}{lcccc}
\hline \hline Accession & ssp $^{2}$ & 1975 & 1976 & 1977 \\
\hline Dove Creek & $\mathrm{t}$ & 111.8 & 103.7 & 99.8 \\
Clear Creek & $\mathrm{t}$ & 90.2 & 90.3 & 91.0 \\
Loa & $\mathrm{t}$ & 91.7 & 87.0 & - \\
Evanston & $\mathrm{t}$ & 63.1 & 77.2 & 74.3 \\
Dog Valley & $\mathrm{t}$ & 67.8 & 75.7 & 69.1 \\
Wingate Mesa & $\mathrm{t}$ & 58.7 & 65.5 & 65.4 \\
Clear Creek & $\mathrm{v}$ & 52.5 & 65.3 & - \\
Pinto Canyon & $\mathrm{v}$ & 50.1 & 58.3 & 57.4 \\
Durkee Springs & $\mathrm{v}$ & 39.1 & 62.0 & 57.9 \\
Salina Canyon & $\mathrm{v}$ & 47.1 & 57.3 & - \\
Indian Peak & $\mathrm{v}$ & 48.6 & 54.1 & 52.1 \\
Petty Bishop's Log & $\mathrm{v}$ & 51.8 & 54.3 & 45.1 \\
Alton & $\mathrm{v}$ & 44.1 & 55.2 & 45.6 \\
Evanston & $\mathrm{w}$ & 41.3 & 54.6 & - \\
Benmore & $\mathrm{v}$ & 46.5 & 57.0 & 38.7 \\
Brush Creek & $\mathrm{t}$ & 42.6 & 52.3 & 40.2 \\
Sardine Pass & $\mathrm{v}$ & 42.5 & 52.1 & 45.3 \\
Milford & $\mathrm{w}$ & 35.9 & 52.8 & 45.0 \\
Colton & $\mathrm{v}$ & 41.8 & 48.0 & 34.8 \\
Kaibab & $\mathrm{w}$ & 37.5 & 46.7 & 34.9 \\
Trough Springs & $\mathrm{w}$ & 30.3 & 41.7 & 30.6 \\
\hline
\end{tabular}

I Based equally on height, crown, and annual biomass production. See section on Data Collection and Analyses (Materials and Methods) for details.

Subspecies: $\mathrm{t}=$ tridentata, $\mathrm{v}=$ vaseyana, $\mathrm{w}=$ wyomingensis.

opposed to annual leader growth $(p<0.05)$. In every case, for all 3 years, basin big sagebrush growth performance parameters exceed significantly those of mountain and Wyoming big sagebrush (Table 6). The last-mentioned two subspecies, on the other hand, do not significantly differ except in one out of nine comparisons. In eight of these nine comparisons, however, mountain big sagebrush means exceed those of Wyoming big sagebrush. The ninth case, annual leader growth for 1976, has equal means (Table 6).

\section{Discussion}

We have demonstrated accessional and subspecies differences in big sagebrush parameters (Tables $2,3,4,5,6$ ). These differences a ugment earlier findings on differences (reviewed by McArthur and Plummer 1978 and Welch and McArthur 1979a) in protein levels, phenolics and terpenoids, seed germination, phenology, palatability, and digestibility.

\section{Height and Crown}

These two measures are correlated quite highly $\left(r^{2}\right.$ for data in Table 3 is 0.86 ). In the uniform garden situation, however, basin big sagebrush has a different height/crown $(\mathrm{h} / \mathrm{c})$ ratio than the other two subspecies. It has an $\mathrm{h} / \mathrm{c}$ ratio of $0.75 \pm 0.03$ (se), whereas mountain big sagebrush's $h / c$ is $0.61 \pm 0.02$ and Wyoming big sagebrush's $\mathrm{h} / \mathrm{c}$ is $0.60 \pm 0.02$ (Table 3). This difference is a reflection of a more upright growth form for basin big sagebrush (Beetle and young 1965, Winward and Tisdale 1977, McArthur et al. 1979).

Our values for height and crown (Table 3 ) are larger than those observed in many natural situations. Apparently, the Snow Fielc Station is a favorable site for good growth parameter expressior for big sagebrush (Table 5). These values are subject to environ mental influence as Kearney et al. (1914) long ago realized. Ther is, however, a genetic or taxonomic component as well, as our dat: (Tables 3,5 ) show. The subspecies occur together in ecotonal area: (Hanks et al. 1973; McArthur et al. 1979) and maintain theil stature diffe rences just as they do in uniform gardens. Whereas ou: values are large, they do not approach those of some large basin bis sagebrush specimens occurring in nature. Pase (1956) reported a plant $475 \mathrm{~cm}$ tall near Kanab. Utah, which he suspected was abou 13 years old. Beetle (1962) reports finding a specimen that was no quite as tall, but had a stem circumference of $165 \mathrm{~cm}$. Van Epps e al. (1982) reported individual biomass production up to 15.9 $\mathrm{kg} /$ plant for big sagebrush growing in favorable locations. Basir big sagebrush is consistently the largest of the subspecies (Table 6 Beetle 1962). Within basin big sagebrush ecotypes and accessions differences exist (Table 3). Hanks et al. (1973) recognized the exceptionally large forms as a specific ecotype which they callec the "fence-row" type because it reaches its maximum size potentia along fence rows and in other protected areas. Hanks et al. (1973 reported that this ecotype produced a characteristic phenolis chromatograph.

We find it interesting that our biggest forms-those with growtl indexes (Table 3) above 60-are diploids (Table 1). The smallest o our basin big sagebrush accessions (Brush Creek and Wingatı Mesa) are tetraploids. These two accessions may have an addi tional genome which codes for smaller size. The four smalles accessions and six of the eight smallest accessions are tetraploid $o$ hexaploid (Tables 1, 4). The smallest subspecies, Wyoming bif sagebrush, is tetraploid with occasional hexaploid plants (McAr thur et al. 1981). The apparent correlation of the gigas forms witl diploidy is contrary to the usual norm in herbaceous plants, bu similar to the situation in the woody saltbushes (Atriplex sp.) o western North America (Stutz et al. 1975, Stutz 1978, Stutz per sonal communication).

\section{Annual Leader Growth Rates and Annual Yield}

These measures were to assess, at least in part, the annua production of big sagebrush. Production estimates show severa orders of mean-value differences among the accessions (Table 3 ) The contrast is more striking for the yield data because as the size of the bush goes up the number of discrete units of productior (twigs) increase in more of an exponential than linear manner Twig length also increases with the size of the bush (Table 3). Ou values for both estimators were highest for basin big sagebrush (Tables 3, 5,6). Mean values for annual leader growth at the Snow Field Station varied from 5.6 to $15.4 \mathrm{~cm}$ for the 1976 growing season. For 1977, the values were generally less, but the range was larger $(4.2$ to $15.6 \mathrm{~cm})$. Unpublished results of McKell and Van Epps illustrate the large influence of weather on annual big sage. brush leader lengths. Average annual leader lengths ranged from a low of $2.5 \mathrm{~cm}$ (1977) to a high of $9.2 \mathrm{~cm}$ (1979) over the 5 -year study near Bonanza, Utah. (Data on file, Institute for Land Rehabilitation, Utah State University, Logan. Utah.) Our values here for annual leader growth are systematically less than those we reported

Table 5. Growth characteristics of three big sagebrush accessions at their natural sites and in two uniform gardens.

\begin{tabular}{|c|c|c|c|c|c|c|c|c|c|}
\hline \multirow[b]{3}{*}{ Location } & \multicolumn{9}{|c|}{ Accession } \\
\hline & \multicolumn{3}{|c|}{ Dove Creek } & \multicolumn{3}{|c|}{ Loa } & \multicolumn{3}{|c|}{ Colton } \\
\hline & $\mathrm{Ht}^{\mathbf{I}}$ & $\mathrm{Cr}^{1}$ & Alg & $\mathrm{Ht}$ & $\mathrm{Cr}$ & Alg & $\mathrm{Ht}$ & $\mathrm{Cr}$ & Alg \\
\hline Snow Field Station & $221.2 \mathrm{a}^{2}$ & $249.2 \mathrm{a}$ & $15.6 \mathrm{a}$ & $156.8 \mathrm{a}$ & $200.2 \mathrm{a}$ & $15.4 \mathrm{a}$ & $92.6 \mathrm{a}$ & $150.6 \mathrm{a}$ & $5.6 \mathrm{a}$ \\
\hline $\begin{array}{l}\text { Natural Site } \\
\text { Gordon Creek Wildlife }\end{array}$ & $144.0 \mathrm{~b}$ & $197.8 \mathrm{a}$ & $7.3 \mathrm{~b}$ & $105.6 \mathrm{~b}$ & $142.8 \mathrm{~b}$ & $5.0 \mathrm{~b}$ & $71.2 \mathrm{a}$ & $151.6 \mathrm{a}$ & $3.7 \mathrm{a}$ \\
\hline Management Area & $123.0 \mathrm{~b}$ & $166.8 \mathrm{a}$ & $12.7 \mathrm{a}$ & $80.8 \mathrm{~b}$ & $130.4 \mathrm{~b}$ & $6.4 \mathrm{~b}$ & $46.6 \mathrm{~b}$ & $94.2 \mathrm{~b}$ & -3 \\
\hline
\end{tabular}

IAbbreviations: $\mathrm{Ht}=$ height, $\mathrm{Cr}=$ crown diameter, $\mathrm{Alg}=$ annual leader growth. All measurements in centimeters.

'Means in each column followed by the same letter are not significantly different $(p<0.01)$ by Tukey's test.

${ }^{3} \mathrm{Alg}$ of Colton accession at Gordon Creek Wildlife Management Area was not collected because of heavy deer browsing. 


\begin{tabular}{|c|c|c|c|c|c|c|c|c|c|}
\hline \multirow[b]{3}{*}{ Subspecies } & \multicolumn{9}{|c|}{ Growth parameters } \\
\hline & \multicolumn{3}{|c|}{ Height } & \multicolumn{3}{|c|}{ Crown } & \multirow{2}{*}{$\begin{array}{l}\text { Yield } \\
1975 \\
\end{array}$} & \multicolumn{2}{|c|}{ Annual leader growth } \\
\hline & 1975 & 1976 & 1977 & 1975 & 1976 & 1977 & & 1976 & 1977 \\
\hline $\begin{array}{l}\text { tridentata } \\
\text { vaseyana } \\
\text { wyomingensis }\end{array}$ & $\begin{array}{c}148.8 \mathrm{a}^{1} \\
96.3 \mathrm{~b} \\
77.3 \mathrm{~b}\end{array}$ & $\begin{array}{r}147.9 \mathrm{a} \\
95.8 \mathrm{~b} \\
77.1 \mathrm{~b}\end{array}$ & $\begin{array}{r}134.8 \mathrm{a} \\
69.3 \mathrm{~b} \\
61.8 \mathrm{~b}\end{array}$ & $\begin{array}{l}193.0 \mathrm{a} \\
153.7 \mathrm{~b} \\
129.6 \mathrm{~b}\end{array}$ & $\begin{array}{l}194.4 \mathrm{a} \\
157.3 \mathrm{~b} \\
129.5 \mathrm{~b}\end{array}$ & $\begin{array}{l}186.1 \mathrm{a} \\
128.3 \mathrm{~b} \\
109.3 \mathrm{~b}\end{array}$ & $\begin{array}{r}2217 \mathrm{a} \\
890 \mathrm{~b} \\
545 \mathrm{~b}\end{array}$ & $\begin{array}{r}12.8 \mathrm{a} \\
8.1 \mathrm{~b} \\
8.1 \mathrm{~b}\end{array}$ & $\begin{array}{r}11.7 \mathrm{a} \\
8.2 \mathrm{~b} \\
5.4 \mathrm{c}\end{array}$ \\
\hline
\end{tabular}

'Means in each column followed by the same letter are not significantly different $(p<0.01)$ by Schieffe's test.

earlier (McArthur et al. 1978, Welch and McArthur 1979a) because we used only the leaders from branches with vertical axes then. In this study, we used the vertical axis branches plus an equal number of branches with more horizontal axes. Our values for annual leader growth are compatible with the values given by Diettert (1938) (6.0 to $15.2 \mathrm{~cm})$ and Winward and Tisdale (1977) $(4.7$ to $11.2 \mathrm{~cm})$. Winward and Tisdale reported, as we do, that basin big sagebrush has higher values than do the other subspecies.

Production of new biomass slows down under unfavorable (dry or cold) growing conditions (DePuit and Caldwell 1973). If circumstances get too bad, the plants die or die back (Ferguson 1964). Plants at the Snow Field Station were still producing substantial amounts of new biomass, however, even after a 2-year drought (Table 6; Richardson et al. 1977).

\section{Implication of Growth Rate Differences}

Accessional and subspecies growth rate differences are real. They lead to different morphological forms. Growth rate parameturs support the division of big sagebrush into subspecies. In fact, they help in subspecies identification (Beetle and Young 1965, Winward and Tisdale 1977, McArthur et al. 1979). A simple chemical test (Stevens and McArthur 1974), however, is a useful adjunct to n. orphological growth characters for field identification because of uneven ages and microsite-induced variation (West et al. 1978).

In our plans for improvement of big sagebrush, growth rate paraneters play an important role (Welch and McArthur 1979a). Whate ver genetic gains in forage quality can be made would be augmelited by making more of the product available on a per bush or per $u$ nit area basis.

\section{Literature Cited}

Beetle, A.A. 1960. A study of sagebrush. The section Tridentatae of Artemisia. Univ. Wyoming Agr. Exp. Sta. Bull. 368.83 p.

Beetle, A.A. 1962. Bigger sagebrush. J. Range Manage. 15:61.

Beetle, A.A. 1971. An ecological contribution to the taxonomy of Artemisia. Madroño 20:385-386.

Beetle, A.A., and A. Young. 1965. A third subspecies in the Artemisia tridentata complex. Rhodora 67:405-406.

Caldwell, M.M. 1979. Physiology of sagebrush. p. 74-85. In: The sagebrush ecosystem: a symposium. Utah State Univ., Logan. 251 p.

Cottam, W.P., and G. Stewart. 1940. Plant succession as a result of grazing and of meadow desiccation by erosion since settlement in 1862 . J. Forestry, 38:613-626.

Daubenmire, R. 1975. Ecology of Artemisia tridentata subsp. tridentata in the State of Washington. Northwest Sci. 49:24-35.

DePuit, E.J., and M.M. Caldwell. 1973. Seasonal pattern of net photosynthesis of Artemisia tridentata. Am. J. Bot. 60:426-435.

Diettert, R.A. 1938. The morphology of Artemisia tridentata Nutt. Lloydia 1:3-74.

Ferguson, C.W. 1964. Annual rings in big sagebrush, Artemisia tridentata. Papers of the Laboratory of Tree-ring Research. No. 1. Univ. Arizona Press, Tucson. 95 p.

Hanks, D.L., E.D. McArthur, R. Stevens, and A.P. Plummer. 1973. Chromatographic characteristics and phylogenetic relationships of Artemisia section Tridentatae. U.S. Dep. Agr. Forest Serv. Res. Pap. INT-141. 24 p.

Harniss, R.O., and R.B. Murray. 1973. 30 years of vegetal change following burning of sagebrush-grass range. J. Range Manage. 26:322-325.

Hays, W.L. 1963. Statistics. Holt, Rinehart, and Winston, Inc. New York. $719 \mathrm{p}$.
Kearney, K.T., L.J. Briggs, H.L. Shantz, J.W. McLane, and R.L. Piemeisel. 1914. Indicator significance of vegetation in Tooele Valley, Utah. J. Agr. Res. 1:365-4I7.

McArthur, E.D. 1979. Sagebrush systematics and evolution. p. 142-22. In: The sagebrush ecosystem: a symposium. Utah State Univ., Logan. 251 p.

McArthur, E.D., A.C. Blauer, A.P. Plummer, and R. Stevens. 1979. Characteristics and hybridization of important Intermountain shrubs. III. Sunflower family. U.S. Dep. Agr. Forest Serv. Res. Pap. INT-220. 82 p.

McArthur, E.D., and D.C. Freeman. 1982. Sex expression in Atriplex canescens: genetics and environment. Submitted to Bot. Gazette.

McArthur, E.D., and A.P. Plummer. 1981. Biogeography and management of native western shrubs: a case study, section Tridentatae of Artemisia. Great Basin Nat. Mem. 2:229-243.

McArthur, E.D., C.L. Pope, and D.C. Freeman. 1981. Chromosomal studies of subgenus Tridentatae of Artemisia: evidence for autopolyploidy. Amer. J. Bot. 68:589-605

McArthur, E.D., B.L. Welch, and R. Stevens. 1978. Growth rates of Artemisia tridentata subspecies. p. 26-27. In: Abstracts of Papers, 3Ist Annual Meetings, Soc. Range Manage., Denver, Colo. 64 p.

Nelson, D.L., and R.G. Krebill. 1981. A sagebrush wilt disease of unknown cause. Great Basin Nat. 41:184-191.

Pase, C.P. 1956. Is this the largest sagebrush plant? J. Range Manage. 9:60. Pearson, L.C. 1975. Daily and seasonal patterns of photosynthesis in Artemisia tridentata. J. Idaho Acad. Sci. 11:11-19.

Pechanec, J.F., and G.D. Pickford. 1937. A weight estimate method for determination of range or pasture production. J. Am. Soc. Agron. 29:894-904.

Plummer, A.P. 1977. Revegetation of disturbed Intermountain area sites. p. 302-339. In: Thomas, J.L. (ed.) Reclamation and use of disturbed land in the Southwest. Univ. Arizona Press, Tucson. 362 p.

Pool, R.J. 1908. Histological studies in the Artemisia formation. Univ. Nebraska Studies 4:411-438.

Price, R., and R.B. Evans. 1937. Climate of the west front of the Wasatch Plateau in central Utah. Monthly Weather Rev. 65:291-301.

Richardson, E.A., P.D. Christensen, W.G. Dewey, R.F. Nielson, G.L. Asheroft, and R.J. Hanks. 1977. Utah's drought-what can we do about it. Utah Sci. 38:3-10.

Roughton, R.D. 1972. Shrub age structures on a mule deer winter range in Colorado. Ecology 53:615-625.

Scholl, J.P., R.G. Kelsey, and F. Shafizadeh. 1977. Involvement of volatile compounds of Artemisia in browse preference by mule deer. Biochem. Syst. Ecol. 5:291-295.

Snedecor, G.W., and W.G. Cochran. 1967. Statistical methods (6th ed.) Iowa State College Press, Ames. 593 p.

Steele, R.G.D., and J.H. Torrie. 1960. Principles and procedures of statistics. McGraw-Hill Book Co., New York. 481 p.

Stevens, R., and E.D. McArthur. 1974. A simple field technique for identification of some sagebrush taxa. J. Range Manage. 27:325-326.

Stutz, H.C. 1978. Chromosome races of shadscale (Atriplex confertifolia) p. 33. In: Abstracts of papers, 31 st Annual Meeting, Soc. Range Manage. Denver, Colo. $64 \mathrm{p}$.

Stutz, H.C., J.M. Melby, and G.K. Livingston. 1975. Evolutionary studies of Atriplex: a relic gigas diploid population of Atriplex canescens. Amer. J. Bot. 62-236-245.

Van Epps, G.A., J.R. Barker, and C.M. McKell. 1982. Energy biomass from large rangeland shrubs of the intermountain United States. Submitted to J. Range Manage. 35:22-25.

Ward, G.H. 1953. Artemisia, section Seriphidium in North America. Contr. Dudley Herb. 4:155-205.

Welch, B.L., and E.D. McArthur. 1979a. Feasibility of improving big sagebrush (Artemisia tridentata) for use on mule deer winter ranges. p. 451-473. In: Goodin, J.R., and D.K. Northington (eds.) Arid land plant resources. Texas Tech Univ., Lubbock. 724 p. 
Welch, B.L., and E.D. Mc Arthur. 1979b. Variation in winter levels of crude protein among Artemisia tridentata subspecies grown in a uniform garden. J. Range Manage. 32:467-469.

Welch, B.L., and E.D. McArthur. 1981. Variation of monoterpenoid content among subspecies and accessions of Artemisia tridentata grown in a uniform garden. J. Range Manage. 34:380-384.

Welch, B.L., E.D. McArthur, and J.N. Davis. 1981. The differential preference of wintering mule deer for accessions of big sagebrush and black sagebrush grown in a uniform garden. to J. Range Manage. 34:409-411.

Welch, B.L., and J.C. Pederson. 1981. In vitro digestibility among accessions of big sagebrush by wild deer inoculum and its relationship to monoterpenoid content. J. Range Manage. 34:497-500.
West, N.E., R.J. Tausch, K.H. Rea, and P.T. Tueller. 1978. Taxonomic determination, distribution, and ecological indicator values of sagebrush within the pinyon-juniper woodlands of the Great Basin. J. Range Manage. 31:87-92.

Winward, A.H. 1970. Taxonomic and ecological relationships of the big sagebrush complex in Idaho. Ph.D. diss. Univer. of Idaho, Moscow, $80 \mathrm{p}$.

Winward, A.H., and E.W. Tisdale. 1977. Taxonomy of the Artemisia tridentata complex in Idaho. Univ. Idaho Forest, Wildlife, and Range Exp. Sta. Bull. No. 19. 15 p.

J.R. Barker's 1981 Ph.D. dissertation (Utah State University, Genetic differences between large and small Artemisia tridentata plants in contiguous populations, $113 \mathrm{p}$.) gives additional support to the concept of genetically controlled size differences in $\mathrm{ssp}$. of $\boldsymbol{A}$. tridentata. 